\title{
Intensi RRC menjadi Adidaya
}

\author{
I Basis Susilo
}

Universitas Airlangga

\begin{abstract}
ABSTRAK
Artikel ini membahas keinginan RRC untuk menjadi adidaya pada abad ke-21 dan mengalahkan AS. Setelah Perang Dingin berakhir, sistem bipolar diganti oleh sistem unipolar, di mana AS sebagai adidaya satu-satunya secara sepihak mengontrol dinamika politik internasional. Para ilmuwan sepakat bahwa unipolaritas itu bersifat sementara, yang akan diganti oleh bipolaritas atau multipolaritas. Salah satu ahli, Christopher Lyane, memprediksi bahwa unipolaritas itu berakhir pada tahun 2010. Makalah ini berasumsi bahwa $R R C$ paling potensial menjadi adidaya menggantikan AS pada abad ke-21 dan bahwa intensitas dan kapasitas adalah dua faktor komplementer yang mendorong proses itu. Makalah ini menemukan bahwa RRC belum menjadi adidaya sampai sekarang, karena memang tidak ada bukti adanya intensitas para pemimpin $R R C$ yang menargetkan $R R C$ menjadi adidaya pada tahun 2015 ini. Para pemimpin RRC memang punya intensitas untuk menjadi adidaya dan mengalahkan AS, tetapi targetnya tidak secepat prediksi Lyane. Ada dua target, yaitu tahun 2049 dan 2100, yang diupayakan oleh semua pemimpin tertinggi $R R C$.
\end{abstract}

Kata-kata kunci: RRC, adidaya, transisi, abad ke-21.

This paper clarifies the intention of the People's Republic of China's intention to become the world superpower in place of the United States. Since the end of the Cold War, the bipolar system has been replaced by the unipolar one whereby the United States shapes and controls the dynamics of international politics. Scholars like Christopher Layne argue that the unipolarity under the United States would not last long, because it would be transformed into the new bipolarity or even multipolarity by 2010. In contrast to Layne's prediction, until 2015 the unipolar order continues to exist, and China is not yet a superpower replacing the United States. This is despite the fact that China has the potentials tosupplant the United States. The paper proposes two complementary factors, intention and capacity, to understand about the position of China over the United States. The point is that there is no evidence indicating that the claim if China wishes to become the superpower. Admittedly, the Chinese leaders do not aim for reaching the superpower status as fast as Layne's prediction. The target is defined in two stages; by 2049 and 2100 .

Keywords: PRC, superpower, the 21st century, transition. 
Setelah Perang Dingin berakhir pada 1989, sistem politik internasional berubah, dari sistem bipolar menjadi sistem unipolar. Dalam sistem bipolar sejak 1945, dua adidaya (superpower), yaitu Amerika Serikat dan Uni Soviet, yang mengendalikan dinamika internasional. Dalam sistem unipolar, hanya satu adidaya yang ada, yaitu Amerika Serikat. Pada awal 1990-an, beberapa ahli hubungan internasional memprediksi bahwa sistem unipolar itu tidak akan berlangsung terus. Artinya, sistem unipolar hanyalah bersifat sementara, yang akan diganti oleh sistem multipolar. Hanya saja, kapan dan bagaimana kesementaraan sistem unipolar itu para ahli berbeda pendapat.

Pada 1991 Charles Krauthammer memprediksi bahwa bipolaritas tidak diganti multipolaritas tetapi oleh unipolaritas, tetapi unipolar itu akan digantikan oleh multipolar pada saatnya nanti. Tulis Krauthammer (1991, 23-24): "The most striking feature of the post-Cold War world is its unipolarity. No doubt, multipolarity will come in time ... But we are not there yet, nor will we be for decades. Now is the unipolar moment." Dua tahun kemudian, Samuel Huntington $(1993,82)$ menyatakan bahwa AS adalah satu-satunya kekuatan yang bisa bertindak sebagai polisi dunia, bahwa bila AS tidak bisa memelihara keamanandunia, tidak ada negara lain atau gabungan negara yang bisa menggantinya. Pada tahun yang sama, Christopher Lyane (1993, 5-51) dan Colin S. Gray (1999, 326)memprediksi unipolaritas pada pasca-Perang Dingin semata-mata suatu interlude geopolitis yang akan memberi jalan bagi multipolar dalam waktu antara 2000 dan 2010 sebagai hasil dari imperatif sistemik untuk menciptakan perimbangan bagi dominasi AS. Kekuatan besar lain akan mencari cara mengimbangi kekuaan AS dan membawa ke suatu multipolaris baru.

Kemudian pada 1999, William Wohlforth (1999, 5-41) menyatakan bahwa tak ada negara lain tampaknya dapat menantang kekuatan AS dalam dimensi-dimensi apapun dalam beberapa dasawarsa; dan bahwa penantang yang mungkin (Rusia, Jerman, RRC dan Jepang) hanya dapat melakukannya sebatas pengimbang pada tingkat lokal dan regional saja.Negara-negara yang diprediksi bisa mengimbangi adidaya AS adalah Uni Eropah, Jepang,dan RRC. Di antara ketiga kekuatan itu, RRC yang paling dianggap bisa mencapai posisi menyaingi AS karena tiga hal. Pertama, Eropah Barat dan Jepang memang kuat, tetapi keduanya sedang menurun kekuatannya. Sedangkan RRC selama tiga dasarwarasa terakhir bergerak mencapai puncaknya setelah lama lemah.

Kedua, Eropa Barat dan Jepang adalah dua kekuatan yang sedikitbanyak mendapat dukungan dan bantuan dari adidaya AS selama bertahun-tahun sehingga bisa bangkit dari krisis Perang Dunia II. Artinya, Eropah Barat dan Jepang mengalami pengaruh duntikan dari luar (exogenous) di samping punya kekuatan-kekuatan dari dalam (endogenous). Sedangkan RRC, tidak seperti Eropah Barat dan Jepang, 
harus bergerak sendiri tanpa bantuan dan dorongan dari adidaya AS pada periode pasca Perang Dunia II. Bahkan dalam keadaan tertentu, RRC mendapat tentangan dan halangan dari adiaya AS sejak Perang Dunia II.

Ketiga, Eropah Barat dan Jepang sudah menjadi masyarakat tua (grey society), di mana sebagian besar masyarakatnya adalah orang tua, bahkan lanjut usia (lansia), sehingga tidak cukup punya daya-bangun untuk menggerakkan masyarakat-negaranya untuk mengejar adidaya AS. Sedangkan RRC masih belum bisa disebut grey society, sehingga masih punya kekuatan muda yang bisa diandalkan untuk menggerakkan roda pembangunan masyarakat-bangsanya untuk mengejar ketertinggalan dari adidaya AS.

Namun, sampai pertengahan tahun 2015 ini, unipolaritas masih berlangsung, dan RRC belum menjadi adidaya seperti yang diprediksi Lyane. Pertanyaannya, mengapa RRC belum bisa menggantikan AS sebagai adidaya? Untuk menjawab pertanyaan itu, diperlukan pemahaman bahwa selalu dua sisi harus dipertimbangkan: intensi dan kapabilitas. Maka diperlukan jawaban atas dua rangkaian pertanyaan berikut. Pertama, apakah ada intensi RRC untuk menjadi adidaya di awal millenium ketiga ini? Kalau ada, seperti apa intensi itu diungkapkan: apakah dalam bentuk road-map atau blue-print jangka pendek atau jangka panjang? Kedua, apakah RRC punya cukup modalitas dan kapasitas untuk menjadi superpower? Apakah kapasitas RRC itu meningkat cepat? Apakah dinamika politik regional dan internasional mendorong atau menghambat proses peningkatan kapasitas RRC itu?

Makalah ini hanya menjawab rangkaian pertama dari dua rangkaian pertanyaan di atas, yaitu: apakah ada intensi RRC untuk menjadi adidaya di awal millenium ketiga ini? Kalau ada, seperti apa intensi itu diungkapkan? Apakah diungkapkan lebih bersifat aspirasional atau didasari oleh perhitungan realistis? Untuk itu, dalam makalah ini ditunjukkan bahwa RRC memang punya intensi kuat untuk menjadi adidaya, tetapi intensi itu semula bersifat aspiratif dan mitologis tanpa didukung oleh realitas yang memadai, yang menghasilkan target tahun 2049 sebagai adidaya yang mengalahkan adidaya AS. Kemudian, setelah bukti-bukti kemajuan menunjukkan adanya kapasitas cukup, intensi RRC menjadi adidaya dibuat secara lebih hati-hati dan realistis, sehingga tidak menutup kemungkinan untuk terwujud pada waktu yang ditargetkan, yaitu adidaya menyamai AS pada 2080, dan mengalahkan AS pada 2100. 


\section{Strategi Realis-ofensif dan Realis-defensif}

Setiap negara dipengaruhi oleh ingatan kolektif atas sejarah masa lalunya. Diktum itu lebih-lebih dirasakan oleh China. Sebagaimana ditulis Jeffrey W. Legro (2008, 163) dan David Shambaugh (2013, 54), sikap dan tindakan China amat dipengaruhi tyranny of history-nya. Persepsi kolektif bangsa China tentang sejarahnya kemudian membentuk ide-ide dominan tentang kebijakan luar negerinya. Dari ingatan dan perasaan kolektif itu muncul beberapa ide dominan: (1) bahwa negeri itu pernah sangat jaya di masa lalu --maha besar, superior, pusat budaya-- sehingga menamakan diri sebagai "negara pusat" yang dikelilingi oleh negara-negara lainnya yang lebih kecil sebagai subordinatnya dalam struktur hubungan yang asimetris; (2) bahwa secara objektif negeri itu amat besar, baik ukuran wilayah maupun penduduknya; (3) bahwa negeri itu pernah dijadikan bulan-bulanan negara-negara Barat dan Jepang dalam masa seratus tahun penghinaan yang memalukan (bainian guochi atau century of shame and humuliation); (4) bahwa dalam seratus tahun penghinaan yang memalukan itu, negeri itu pernah bermasalah dengan integrasi wilayah, integrasi budaya, dan bahkan integrasi nasionalnya.

Seperti halnya Legro dan Shambaugh, Tang Shiping (2008, 153) juga menulis: "Many Chinese elites believe that because of its size, population, civilization, history and, more recently, its growing wealth, China should be regarded as a great power (da guo)." Namun perlu dicatat di sini bahwa kejayaan China pada masa lalu itu sebenarnya hanya terbatas pada wilayah Asia Timur, sebagaimana ditulis oleh Avery Glodsten (2008, 76-77):

... the dominant role Imperial China filled during many centuries when Easy Asia was an international system largerly separated from those in the Middle East and Europe. ... there was a long tradition that the capital of China was center of an administrative entity whose sway, though not control, exrended throughout much of East Asia and whose leadership, though not complete authority, was acknowledged in various ways by many nominally independent neighboring countries.

Atas dasar ide-ide dominan itu, apa yang harus dilakukan oleh siapa pun pemimpin China adalah mengembalikan kejayaan itu, sehingga --dalam istilah Kissisnger-- China lebih merupakan a returning power daripada a rising power (Shambaugh 2013, 1). Aspirasi untuk mengalahkan adidaya lain selalu ada dalam setiap pemimpin China. Hanya persoalan bagaimana mengalahkan dan kapan target kemenangannya tentunya bersifat dinamis tergantung karakter dan pilihan pemimpin yang sedang berkuasa dalam mendefinisikan situasi jamannya dan memprediksi dinamika internasional masadepannya. 
Tentang karakter RRC dalam menghadapi dunia luar, Shiping (2008, 148-156) mengenalkan dua pembedaan: realis-ofensif dan realisdefensif. Karakter pada masa Mao pada dasarnya realis-ofensif, sementara sejak pada masa Deng dan setelahnya pada dasarnya realis defensif. Pada masa Mao, RRC menganut ideologi yang intoleran untuk membuang semua rejim imperialis dan reaksioner di seluruh dunia, dan atas dasar ideologi Marxist-Leninis meyakini konflik dalam politik internasional perlu dan memang tidak terhindarkan dalam rangka perjuangan melawan imperialis dan dalam mentransformasikan dunia ke dalam dunia sosialis. Bahkan RRC tidak mempraktikkan pengekangan diri dan tidak ingin dikekang oleh negara-negara lain. Sedangkan sejak Deng memimpin RRC, RRC mulai membuka diri dan bersedia bekerjasama dengan komunitas internasional.

Strategi realis-ofensif dan realis-defensif sebenarnya diabdikan pada tujuan yang sama, yaitu menjadikan China menjadi adidaya. Intensi untuk menjadi adidaya, dan bahkan mengalahkan adidaya AS, sudah ada sejak RRC berdiri pada tahun 1949. Bisa dipahami bila ide-ide dominan dalam hubungan luar negeri RRC itu juga mempengaruhi Mao. Intensi itu muncul dari rasa percaya diri sebagai bangsa yang besar di satu pihak, dan dari ingatan kolektif bangsa China berupa penghinaan seabad oleh bangsa-bangsa Barat dan Jepang.

\section{Intensi Mao: Adidaya pada 2049}

Diungkap oleh Larry Getlen (2015) bahwa Michael Pillsbury --ahli tentang China dan bekerja sebagai penasehat kepresidenan AS sejak Richard M Nixon, penulis buku The Hundred-Year Marathon: China's Secret Strategy to Replace America as the Global Superpower (2015)-menemukan fakta bahwa kalangan pemimpin China mengenal konsep "Assassin's Mace" (Gada Pembunuh) yang merujuk pada senjata dalam cerita rakyat China yang menjamin kemenangan kombatan kecil atas musuh yang lebih besar dan lebih powerful. Dalam konteks militer, Assassin's Mace ini merujuk pada serangkaian senjata asimetris yang memungkinkan kekuatan inferior mengalahkan musuh yang superior dengan cara menyerang pada titik terlemah musuh. Pillsbury percaya bahwa "The Assassin's Mace ... was part of a cunning and much broader strategy, a 100-year-long effort to overtake the US as the world's superpower" (Getlen 2015).

Pillsbury semula menganggap konsep Assassin's Mace ini bersifat aspirasional semata-mata, tetapi kemudian menemukan bahwa pemerintah RRC telah mengeluarkan dana miliaran dollar untuk mengembangkan konsep itu (Getlen 2015) untuk "make a generational leap in military capabilities that can be trump the conventional forces of 
Western powers”. Bahkan sejak bergerilya pada 1930-an, menurut Pillsbury, Mao selalu mempunyai intensi untuk mengalahkan negaranegara Barat dan Jepang yang menghina China selama seabad, dengan selalu membawa dan membaca buku The General Mirror for the Aid of Government sebagai a statecraft manual with lessons from history that have no Western counterpart yang diambil dan disarikan dari sejarah China sejak 4.00o Sebelum Masehi.

Menurut Pillsbury (Getlen 2015), Mao selalu membawa impian bahwa RRC akan menjadi adidaya menyamai (dan kemudian mengalahkan) AS pada tahun 2049, atau tepat satu abad setelah kemerdekaan 1 Oktober 1949. Mao dan pemimpin-pemimpin RRC kemudian selalu mengandalkan Assassin's Mace sebagai pendekatan klasik warring states, yang berasumsi bahwa China mempertimbangkan perang fisik hanyalah satu aspek kecil dari peperangan, bahwa senjata utama China adalah pengelabuhan (deception), penampilan terus-menerus dari perolehan yang kurang dari yang seharusnya dan bagaimana mendapatkan bantuan (dari luar, bahkan musuh utama) lebih banyak daripada yang dibutuhkan.

Tentang bagaimana RRC memandang sistem dunia, Shiping (2008, 1634) juga menjelaskan bahwa Mao (dan para pemimpin berikutnya) mempunyai kesadaran untuk mengatasi ingatan "seratus tahun penghinaan yang memalukan" (bainian guochi) oleh Barat dan Jepang dengan membangun China yang kuat dan sejahtera. Dalam hal ini, masih menurut Shiping, dengan sistem komunismenya Mao mengutamakan konfrontasi dan menentang masyarakat internasional yang dominan (dan yang kapitalistis) pada saat itu, dengan beberapa cara: semula beraliansi dengan Uni Soviet, kemudian memimpin Dunia Ketiga, lalu self-reliance, isolasi-diri, dan kemudian "mendekati" AS dengan diplomasi ping-pong.

Pandangan Mao itu mengilhami Xi Jinping pada tahun 2013. Tulisan Jeremy Page (2013) menjelaskan keinginan keras Xi untuk melampaui AS pada 2049, tepat 100 tahun setelah RRC berdiri. Keinginan Xi ini penting mengingat ia baru saja menjadi pimpinan Partai Komunis dan militer Cina. Xi amat sering menegaskan perlunya Impian Cina, yang ide dasarnya berasal dari buku berjudul The China Dream yang ditulis Kolonel Liu Mingfu pada 2010. Ketika pertama kali diterbitkan, buku itu disembunyikan, karena pemerintah takut kalau buku itu merusak hubungannya dengan AS. Tetapi setelah Xi menyebut-nyebut Impian Cina setelah diangkat sebagai pimpinan Partai Komunis Cina, maka buku itu diterbitkan ulang pada 2013 dan dijadikan salah satu buku penting yang direkomendasikan untuk harus dibaca. Isi buku itu berargumen bahwa China harus melampaui AS sebagai kekuatan militer terkuat dunia. Senada isi buku itu, Xi menyatakan bahwa untuk mencapai bangkitnya secara besar bangsa China, China harus 
menjamin adanya penyatuan antara negara yang sejahtera dan militer yang kuat "... to achieve the great revival of the Chinese nation, we must ensure there is uni[s]on between a prosperous country and strong military." Xi bahkan sudah menyetel waktu tepatnya untuk pemenuhan impiannya itu, yaitu 2049, 100 tahun ulang tahun Komunis mengambil kekuasaan RRC (Page 2013).

Dalam "Pengantar" dari buku The China Dream, Jendral Liu Yazhou menulis:

The competition between China and the U.S. in the 21st century should be a race, that is, a contest to see whose development results are better, whose comprehensive national power can rise faster, and to finally decide who can become the champion to lead world progress (Page 2013).

\section{Intensi Pasca-Mao: Adidaya pada 2080}

Menurut Zhu Feng (2008, 46-47), beda dari Mao yang ofensif dan agresif, sebagai penganut realis-defensif Deng mempunyai kebijakan yang "'coolly observe, calmly deal with yhings, hold one's position, hide our capabilities and bide our time, and accomplish things when possible' (lengjing guancha, chen zhuo yingfu, wenzhu zhenjiao, taoguang yanghui, yousuo zuowei). Memang tidak mengenakkan untuk ukuran kemajuan militer, tetapi kebijakan ini lebih menguntungkan bagi stabilitas politik dan pembangunan ekonomi jangka panjang.

Deng lebih memilih pendekatan integrasionis terhadap masyarakat internasional. Selama tiga dasawarsa, dasar dari hubungan internasional China adalah prinsip taoguang yanghui yang artinya hiding capabilities and biding one's time yang dipromosikan oleg Deng sebelumnya. Pada 1978 Deng mengatakan "bila China ingin memodernisasi pertanian, industri dan pertahanan, maka yang harus dimodernisasi lebih dulu adalah sains dan teknologi dan menjadikannya kekuatan produktif." Kekuatan Barat terletak pada penggunaan dan penguasaan atas sains dan teknologi, sehingga untuk memajukan RRC diperlukan kerjasama dengan Barat untuk mendapatkan sains dan teknologi itu. Menurut Deng, pendidikan harus menjadi pilar dasar kemajuan. Tampaknya Deng mempercayai pola dan tahapan renaisans: revolusi sains dulu, disusul revolusi teknologi, revolusi industri, lalu revolusi ekonomi (Susilo, 2007).

Tentang sikap dasar Deng Xiao-ping --yang lebih dipengaruhi pendekatan realistik dan saintifik dengan menggunakan aset dan kekuatan dari masalalu maupun masakini, dan dari China sendiri dan dari luar China--ditulis oleh Deng Maomao (1995, 469): 


\section{Basis Susilo}

Deng Xiaoping was already seventy-five years old when he was reinstated the third time. He did not change his tenacious work style, which he had had for decades, his bold way of thinking, or his firm convictions. His conviction was that a new path of development, suited to China, could be blazed by taking a realistic and scientific approach and by making use of a multitude of assets and strength, both ancient and modern, both Chinese and foreign.

Intensi dan roadmap RRC menjadi adidaya menurut Deng Xiao-ping dicapai pada 2049 sebagaimana ditulis oleh Deng Maomao (1995, 470):

Like an architect, Deng Xiaoping drew a completely new blueprint of development for his motherland. By the end of the 1980 s the gross national product of 1980 was to be doubled so as to solve first the problem of food and clothing for the 1.1 billion Chinese people. By the end of the century the 1980 GNP was to be quadrupled so that the Chinese people would have moved from simply having adequate food and clothing to being fairly well off. By the middle of the next century, when we celebrate the one hundredth anniversary of the founding of the People's Republic of China, China, with a population of one and half billion, is to rank with the moderately developed countries in per capita GNP. The Chinese people will become prosperous, and modernization will be basically realized by then.

Oleh karena itu, bisa dikatakan bahwa peletak dasar RRC moderen adalah Deng yang pada 1985 secara strategis mencanangkan empat modernisasi, salah satunya yang terpenting adalah reformasi bidang pendidikan. Dan kalau dilihat lebih awal lagi, kemajuan ekonomi itu saat ini adalah hasil dari keputusan para pemimpin RRC pada tahun 1978 ketika mereka mulai mengimplementasi reformasi dan kebijakan pintu terbuka.

Reformasi di bidang pendidikan itu dijelaskan oleh Li Lanqing, mantan Wakil PM, bahwa RRC telah berhasil dalam pembangunan bidang pendidikan, baik dasar, menengah maupun tinggi, serta vokasional. Sejak awal 1990-an, guru dan kaum profesional sangat dihargai di China. Dalam program reformasi pendidikan yang diinginkan Deng pada tahun 1985 secara eksplisit diungkapkan pentingnya pendidikan karakter. Reformasi pendidikan itu diarahkan untuk melibatkan aspek kognitif, emosi, dan fisik serta akhlak mulia agar anak didik bias mengembangkan potensinya secara maksimal dan selalu hidup secara produktif. Reformasi pendidikan itu membentuk SDM yang cocok untuk dunia moderen sekarang ini.

Kemudian Jiang Zemin pada 1989 menaikkan anggaran militer tetapi tetap menempatkan fokusnya pada pembangunan kapasitas untuk mempertahankan perbatsaan dan mengambil Taiwan. Pada 2002, ketika menjadi ketua partai, Hu tetap merendah karena Jiang masih berkuasa 
sampai 2004. Hu masih memfokuskan pada kenaikan damai (peaceful rise) China yang kemudian menjadi pembangunan damai (peaceful development), yang pada dasarnya masih saja berkarakter defensif. Dikatakan Henry Kissinger, tidak seperti AS yang seperti seorang cow boy sering menunjukkan ototnya, China sebisanya berusaha untuk menghindari penggunaan militer dan "mencapai sasarannya melalui suatu pengamatan yang teliti, kesabaran, dan akumulasi nuansa."

Intensi RRC menjadi superpower yang lebih tegas diumumkan pada 18 Februari 2005, ketika Pusat Penelitian Modernisasi China menerbitkan Roadmap Modernisasi China. Roadmap itu dibuat untuk seabad pertama millenium ketiga. Dengan mempertimbangkan pelbagai faktor, roadmap itu secara tegas menargetkan GDP RRC akan menyamai Jepang pada 2020. Lalu pada tahun 2050, RRC akan menjadi negara maju secara moderat (moderately developed country) dan sudah masuk dalam ranking top 40 negara-negara maju. Pada tahun 2080 RRC bisa menjadi negara maju (developed country) setara dengan AS. Kemudian pada tahun 2100 RRC jadi negara paling maju di dunia, melampaui AS (Susilo 2007). Ini kemudian mendorong Dewan Negara RRC (People's Republic of China State Council) mengeluarkan dokumen resmi China's Peaceful Development Road pada Desember 2005. Tentang dokumen ini ditulis oleh Robert G. Sutter $(2008,4)$ sebagai berikut:

The State Council of the PRC issued a white paper from its Information Office in December 2005 that provided an outline of this view of China's strategy in foreign affairs. Entitled 'China's Peaceful Development Road' the document stresses that achieving peaceful development has been the "unremitting pursuit" of the Chinese people and administration for almost thirty years.

Mengapa baru pada tahun 2005 roadmap itu diumumkan? Jawabnya, justru karena para pemimpin RRC merasa lebih percaya diri setelah mendapati kenyataan bahwa RRC bertumbuh secara mantab di tahuntahun setelah 1980-an. Artinya, niat atau intensitas itu tidaklah out of nothing, tetapi timbul dari kenyataan riil berupa pertumbuhan (terutama ekonomi) yang dialaminya setelah ada empat modernisasi. Justru karena roadmap itu dibuat atas dasar realitas, sehingga realistis, maka roadmap itu menjadi masuk akal dan bisa dicapai.

Untuk mencapai sasaran strategis jangka panjang itu, para pemimpin RRC tidak bisa menggunakan otot belaka, tetapi mengandalkan sains dan teknologi. Hal ini tampak dari keputusan Oktober 2005 dari Rapat Komite Pusat Partai Komunis China yang menyepakati cetak biru pembangunan ekonomi dan sosial untuk Rencana Pembangunan Lima Tahun (Repelita) yang ke-11 (2006-2010). Intinya, pembangunan harus menyelaraskan sektor pertanian dan industri. Komite itu menerima kritik bahwa pembangunan selama ini terlalu berat ke sektor manufaktur yang bernilai rendah untuk keuntungan konsumsi warga 


\section{Basis Susilo}

negara lain, dengan menggunakan banyak lahan, sumber daya alam dan sumberdaya manusia China, yang mengancam ekosistem negerinya. Komite juga menerima kritik bahwa selama bertahun-tahun uang pemerintah dan dana bank milik negara telah membiayai banyak proyek besar tetapi juga banyak dana dipakai untuk membangun hal yang tidak bermanfaat seperti plaza-plaza di pelbagai kota dan taman-taman untuk teknologi tinggi namun masih tetap kosong. Kritik juga mengatakan bahwa investasi besar-besaran telah menyebabkan penggunaan baja dan enerji yang terlalu banyak, sehingga menyebabkan tekanan inflasi dan kekhawatiran akan hancurnya sumber daya alam yang kalau tidak dibatasi akan menyebabkan RRC tergantung pada impor.

Rapat Komite Pusat PKC itu sepakat untuk mengikuti pola kemajuan Barat, yaitu menekankan kemajuan teknologi dan menggunakan lebih sedikit sumberdaya alam dan manusia. Ke depan, pembangunan China secara mendasar akan mengutamakan pemanfaatan teknologi lebih daripada penggunaan sumberdaya alam dan manusia seperti selama ini.Penggunaan sains dan teknologi, kalau berhasil, akan meningkatkan pertumbuhan ekonomi RRC secara meyakinkan. Artinya roadmap akan lebih mudah dijalani. Karena jumlah penduduk yang hampir 1/2 miliar, bila semua produktif dan berbasis sains dan teknologi, maka tidak bisa dibendung lagi kekuatan RRC menjadi adidaya menandingi AS. Apalagi AS, adidaya satu-satunya saat ini, sibuk menghabiskan enerjinya untuk memerangi musuh-musuhnya dan melawan terorisme internasional.

\section{Simpulan}

RRC belum menjadi adidaya pada dasawarsa pertama abad ke-21, karena memang tidak ada pemimpin RRC yang mengekspos intensi untuk menjadi adidaya dengan jadwal secepat (2010) itu. Intensi RRC untuk menjadi adidaya dan mengalahkan AS memang ada, walaupun ada yang aspirasional dan yang realistis. Ada perubahan karakter dan strategi dalam mencapai tujuan menjadi adidaya itu. Pada masa Mao, karakter dan strategi lebih dominan disebut realis-ofensif. Kendati di akhir kekuasaannya, Mao pun sudah menunjukkan sinyal-sinyal bagi perubahan karakter dan strategi yang realis-defensif. Pada masa PascaMao, atau sejak Deng berkuasa, karaker dan strategi lebih dominan disebut realis-defensif, di mana RRC mulai membuka diri dan bersifat integrasionis terhadap komunitas internasional. Strategi realis-defensif itu didasari tuntutan untuk mendapatkan modal dan ilmu pengetahuan dan teknologi. Ternyata strategi realis-defensif ini membuahkan hasil berupa kemajuan di segala bidang, khususnya bidang ekonomi, sehingga lebih menjadi dasar bagi pencapaian intensi untuk menjadi adidaya dan mengalahkan adidaya AS. 
Menjawab pertanyaan "mengapa RRC belum menjadi adidaya pada 2010?" ternyata tidaklah sulit. Mengingat untuk maju dan menjadi adidaya, setidak-tidaknya suatu negara-bangsa harus punya dua hal: niat atau intensi dan kapasitas. Apalagi kalau statusnya sekarang masih belum menjadi adidaya, atau masih menjadi calon adidaya. Dari faktor niat atau intensi ini ditemukan bukti kuat bahwa para pemimpin RRC memang punya intensi untuk menjadi adidaya. Namun, tidak ada data yang membuktikan adanya pemimpin RRC yang menargetkan RRC menjadi adidaya pada tahun 2010 .

Para pemimpin RRC, sejak Mao sampai Xi, sebenarnya bisa dinyatakan sebagai para realis, tetapi realisme mereka bisa dibagi menjadi dua: realis-ofensif dan realis-defensif. Mereka yang realis-ofensif melihat dirinya amat kuat dan mendorong negara-negara lain secara ofensif. Mereka ini menyalahkan komunitas internasional, terutama yang bersistem kapitalisme, yang menyebabkan China lemah, dan menuntut dunia internasional untuk membayar "utang-utang" kepada China. Mereka juga maunya merubah sistem internasional supaya mengikuti sistem sosialisme-komunisme sebagaimana dipilih oleh RRC.

Mereka yang realis-defensif sebenarnya mengakui adanya kelemahan dalam dirinya, sehingga mengakui adanya kekurangan yang bisa diatasi dengan bekerjasama dengan komunitas internasional. Mereka ini tidaklah terlalu ideologis, tetapi lebih melihat kerjasama dengan komunitas internasional, termasuk yang kapitalis, untuk mendorong kemajuan RRC. Strategi yang diambil para realis-defensif ini beda dari para realis-ofensif. Bila para realis-ofensif menyerang komunitas internasional dan mau mengubahnya seperti sistem sosialismekomunisme, maka para realis-defensif mengakomodasi kerjasama dengan komunitas internasional untuk mendapatkan apa-apa yang dibutuhkan RRC untuk maju dan berkembang menjadi adidaya.

Namun, baik para realis-ofensif maupun realis-defensif punya target yang sama dan serupa, yaitu RRC menjadi adidaya mengalahkan AS pada abad ke-21 ini. Hanya saja, kapan tahun persisnya di abad ke-21 ini yang ditargetkan, terdapat beberapa perbedaan. Di satu sisi, Mao, Deng dan Xi mempunyai target tahun 2049 RRC harus menjadi adidaya yang menyaingi AS. Target 2049 diambil lebih sebagai angka keramat yang mudah diingat dan diterima oleh rakyat China, karena tahun itulah RRC berusia 100 tahun. Di lain sisi, data yang diekspos oleh Lembaga Riset Modenisasi China pada 2005, menunjukkan secara lebih realistis: yaitu 2080 adidaya menyamai AS, dan 2100 adidaya mengalahkan atau melampaui AS.

Dalam hal target menjadi adidaya ini ada hal yang menarik, yaitu bahwa ketika didasari oleh rasa percaya diri yang memadai karena kemajuan dan rata-rata pertumbuhan kapasitas negeri yang menakjubkan dunia 
selama 30 tahun belakangan ini, justru target yang dicanangkan untuk menjadi adidaya mengalahkan AS tidak dipercepat, tetapi malah diperlongar menjadi tahun 2100. Meminjam istilah Gray (1993, 326), pada abad ke-20 intensi dan target adalah "more political than strategic.”

Tentu saja, mana target yang akan dicapai tergantung sejarah di kemudian hari. Bila kemajuan dan pertumbuhan RRC konsisten seperti tiga dasawarsa terakhir ini, maka target 2049 maupun 2080 bisa tercapai. Namun, kalau RRC di abad ke-21 ini menghadapi problem internal, dan tidak bisa menghadapi dinamika regional dan internasional-nya secara produktif bagi kemajuan dan pertumbuhannya (apalagi kalau AS dan calon-calon adidaya lainnya mengganggu kemajuan dan pertumbuhan ekonomi RRC) sehingga menghasilkan pola hubungan yang konfliktif, bisa diperkirakan bahwa target 2049 itu akan tidak tercapai. Kalau demikian, target tahun 2080 dan 2100 tampaknya menjadi target yang lebih realistis, karena didasari perhitungan ilmiah yang lebih realistis. Itu pun juga masih belum bisa dipastikan.

Hanya perlu diingat, bahwa transisi menjadi adidaya ini biasa terjadi dalam sejarah dunia ini. Saat ini AS yang menjadi dominan dan mengatur dunia (Pax Americana), sebelumnya Pax Britanica, Pax Romana, dan lain-lainnya, maka tidaklah mustahil akan ada Pax Sinica pada abad ke-22 nanti, yang kemudian akan diganti oleh penantangpenantang lain.

\section{Daftar Pustaka}

\section{Buku}

Friedman, Thomas L., 2005. The World Is Flat: A Brief History of the Twenty-First Century.Farrar, Strauss and Giroux.

Goldstein, Avery, 2008. "Parsing China's Rise: International Circumstances and National Attributes," dalam Robert S. Ross and Zhu Feng (eds.), 2008. China's Ascent: Power, Security, and the Future of International Politics. Ithaca and London: Cornell University Press, 55-86.

Gray, Colin S., 1999. Modern Strategy. Oxford: Oxford University Press. Legro, Jeffrey W., 2008. "Purpose Transtitions: China's Rise and the American Response," dalam Robert S. Ross and Zhu Feng (eds.), 2008. China's Ascent: Power, Security, and the Future of 
International Politics. Ithaca and London: Cornell University Press, $163-187$.

Maomao, Deng, 1995. Deng Xiaoping: My Father. New York: BasicBooks.

Ross, Robert S., and Zhu Feng (eds.), 2008. China's Ascent: Power, Security, and the Future of International Politics. Ithaca and London: Cornell University Press.

Sachs, Jeffrey, 2005. The End of Poverty: How We Can Make It Happen In Our Lifetime.New York: Penguin Press.

Shambaugh, David, 2013. China Goes Global: The Partial Power. Oxford and New York: Oxford University Press.

Shiping, Tang, 2008. "From Offensive to Defensive Realism: A Social Evolutionary Interpretation of China's Security Strategy," dalam Robert S. Ross and Zhu Feng (eds.), 2008. China's Ascent: Power, Security, and the Future of International Politics. Ithaca and London: Cornell University Press, 141-162.

Sutter, Robert G., 2008. Chinese Foreign Relations: Power and Policy Since the Cold War. Lanham, Maryland: Rowman \& Littlefield Publishers, Inc.

Zhu, Feng, 2008, "China's Rise Will Be Peaceful: How Unipolarity Matters," dalam Robert S. Ross and Zhu Feng (eds.), 2008. China's Ascent: Power, Security, and the Future of International Politics. Ithaca and London: Cornell University Press, 14-54.

\section{Artikel Jurnal}

Huntington, Samuel P., 1993. "The Clash of Civilization?," Foreign Affairs (Summer).

Huntington, Samuel, 1993. "Why International Primacy Matters," International Security17(4), dalam Sean M. Lynn-Jones and Steven E. Miller (eds.), 1994. The Cold War and After: Prospects for Peace. Expanded Edition. Cambridge, Massachusetts: The MIT Press, 307-322.

Krauthammer, Charles, 1991. "The Unipolar Moment," Foreign Affairs7o(1): 23-33.

Lee, Jason, 2015. "The World Is Too Important to Be Left to America". Reuters, 4 June.

Lyane, Christopher, 1993. "The Unipolar Illusion: Why New Great Powers Will Rise," International Security17(4), in Sean M. LynnJones and Steven E. Miller (eds.), 1994. The Cold War and After: Prospects for Peace. Expanded Edition. Cambridge, Massachusetts: The MIT Press, 244-290.

Susilo, I Basis, 2004. "RRC Calon Adidaya Baru," Jawa Pos, 20 Januari. Susilo, I Basis, 2007. "Jalan Menuju Adidaya," Jawa Pos, Februari. 


\section{Basis Susilo}

Wohlforth, William, 1999. "The Stability of a Unipolar World," International Security 24(1): 5-41.

\section{Artikel Online}

Getlen, Larry, 2015. "China's secret plan to topple the US as the world's superpower," New York Post, 8 February 2015. Diambil dari http://nypost.com/2015/02/o8/chinas-secret-plan-to-topplethe-us-as-the-worlds-superpower, diunduh 4 November 2015, pada 10.00 WIB.

Moran, Robert, 2015. "Global Perceptions of China as a Super Power."http://myinforms.com/en/a/15516692-robert-moranglobal-perceptions-of-china-as-a-superpower/ diunduh pada 26 Oktober 2015 . 